\title{
EVALUASI PENGENDALIAN KUALITAS AIR MINUM PADA DEPOT AIR MINUM ISI ULANG DI KABUPATEN SLEMAN, YOGYAKARTA
}

\author{
Baziedy Aditya Darmawan (07311050) \\ Jurusan Manjemen Fakultas Ekonomi Universitas Islam Indonesia
}

\begin{abstract}
Water situation is problematic to make people choose to consume bottled drinking water. However, the more expensive bottled drinking water on the market, making people switch to consume water from a much cheaper DAMIU. Although less expensive, not all products DAMIU security guaranteed. Some of the findings mentioned that DAMIU in some major cities do not fit the standards specified in Permenkes Number 907/Menkes/SKVII/2002. The problem in this study is, whether there are deviations in product quality DAMIU in Sleman district, and what factors influence it. The method used is the method of Statistical Quality Control and Ishikawa Diagram. This finding states that there are irregularities which do not fit the quality standards of the content of E-coli, $\mathrm{pH}$, and Fe.
\end{abstract}

Key words: Control, Quality, Depot, Water, Drinking

\section{PENDAHULUAN}

Air merupakan sumber kehidupan yang sangat penting. Air adalah zat atau materi atau unsur yang penting bagi semua bentuk kehidupan yang diketahui sampai saat ini di bumi. Air merupakan kebutuhan yang paling utama bagi makhluk hidup, termasuk manusia. Semua makhluk hidup sangat bergantung dengan air demi mempertahankan hidupnya, terutama untuk dikonsumsi sebagai air minum.
Mayoritas dari komposisi tubuh manusia adalah air (cairan). Karena itu, air memegang peranan yang sangat penting dan tidak tergantikan untuk menjamin kelancaran proses metabolisme di dalam tubuh. Kekurangan air akan menyebabkan tubuh mengalami dehidrasi. Kekurangan air menyebabkan sel kehilangan komponen intinya dan kondisi ini akan menganggu metabolisme. Pada tingkat berat, dehidrasi bisa menyebabkan kematian. 
Air merupakan komponen esensial yang tidak bisa disintesa oleh tubuh. Sehingga, air harus diperoleh dari luar tubuh. Karena fungsi air yang sangat penting bagi tubuh, maka tubuh harus memperoleh air dalam dosis yang cukup setiap hari. Jumlah ideal yang harus dikonsumsi adalah dua liter per hari yang merupakan jumlah total cairan yang masuk ke dalam tubuh.

Air minum adalah air yang digunakan untuk konsumsi manusia. $\mathrm{Na-}$ mun, tidak semua air yang ada layak dan aman untuk diminum. Pada kenyataannya air mempunyai kandungan zat-zat yang dapat mengganggu kesehatan. Jika air yang digunakan belum memenuhi standar kualitas air bersih, akibatnya akan menimbulkan masalah lain yang dapat menimbulkan kerugian bagi penggunanya.

Dalam Peraturan Menteri Kesehatan Nomor 907/ Menkes/ SK/ VII/ 2002, syarat-syarat air minum adalah tidak berasa, tidak berbau, tidak berwarna, tidak mengandung mikroorganisme yang berbahaya. Air yang digunakan untuk konsumsi sehari-hari harus memenuhi standar kualitas tersebut. Kualitas air bersih dapat ditinjau dari segi fisik, kimia, dan mikrobiologi.

Keterbatasan air yang disediakan oleh Pemerintah dan keadaan air yang bermasalah melahirkan ide untuk memproduksi AMDK (Air Minum Dalam Kemasan). Semakin menurunnya kualitas air sumur akibat banyaknya pence- maran dan belum optimalnya pasokan air PDAM dalam jumlah dan kualitas yang cukup menjadi alasan bagi sebagian masyarakat untuk mengkonsumsi AMDK untuk memenuhi kebutuhan air minum keluarga sehari-hari. Namun seiring berjalannya waktu, harga AMDK terus melonjak yang tentu saja membuat sebagian masyarakat kesulitan untuk membeli AMDK. Dengan kondisi tersebut, muncul ide tentang Depot Air Minum Isi Ulang (DAMIU). Keberadaan DAMIU di Kabupaten Sleman, Yogyakarta yang merupakan kota pelajar tidak dapat dipungkiri lagi. Kita sering menjumpai DAMIU tersebut di banyak tempat. Harga yang jauh lebih murah dibandingkan dengan AMDK membuat sebagian masyarakat berganti untuk mengkonsumsi air minum DAMIU sebagai air minum keluarga sehari-hari.

Menurut Siswanto (dalam Shofyan Zuhri, 2009) masyarakat atau pasar masih memiliki persepsi bahwa depot air minum isi ulang ini air bakunya adalah berasal dari sumber mata air pegunungan yang memenuhi syarat-syarat kesehatan. Dalam kenyataannya tidak demikian, air baku dapat diambil dari berbagai sumber. Higienitas depot air minum isi ulang memang tidak dapat ditentukan. Selain kualitas peralatannya, tergantung pula kemampuan dan ketaatan tenaga yang mengoperasikan peralatan tersebut termasuk sikap dan perilaku bersih dan sehatnya. Tenaga yang mengoperasikan dan menangani 
hasil olahan yang tidak berperilaku bersih dan sehat dapat mencemari hasil olahan.

Manik Widiyanti \& Ristiati, 2004) menjelaskan bahwa meski lebih murah, tidak semua depo air minum isi ulang terjamin keamanan produknya. Hasil pengujian laboratorium yang dilakukan Badan Pengawas Obat dan Makanan (POM) atas kualitas depot air minum isi ulang di Jakarta menunjukkan adanya cemaran mikroba dan logam berat pada sejumlah contoh.

Keberadaan DAMIU terus meningkat sejalan dengan dinamika keperluan masyarakat terhadap air minum yang bermutu dan aman untuk di konsumsi. Meski lebih murah, tidak semua DAMIU terjamin keamanan produknya. Hasil pengujian laboratorium yang dilakukan Badan Pengawas Obat dan Makanan (BPOM) atas kualitas depot air minum isi ulang di Jakarta bahwa dari 96 depot air minum isi ulang, $20 \%$ tercemar bakteri coli form dan logam berat pada sejumlah sampel, hal ini tidak layak untuk mengkonsumsi sebagai air minum (Zuhri, 2009).

Hastaryo (dalam Firdaus Yustisia Sembiring, 2008) menemukan 6 depot air minum isi ulang $(9,4 \%)$ dari 31 sampel di Kabupaten Sleman tidak memenuhi syarat kesehatan. Selanjutnya dikatakan bahwa yang berpengaruh terhadap kualitas air minum isi ulang salah satu faktor adalah tingkat pendidikan dan pengetahuan pengelola.
Persyaratan kualitas air minum sebenarnya telah diatur secara jelas dalam Keputusan Menteri Kesehatan Nomor 907/Menkes/SKNII/2002 tentang Syarat-Syarat dan Pengawasan Kualitas Air Minum. Selain itu, persyaratan teknis Depot Air Minum Isi Ulang juga diatur dalam Keputusan Menteri Perindustrian dan Perdagangan Republik Indonesia Nomor 651/MPP/Kep/10/ 2004 tentang Persyaratan Teknis Depot Air Minum dan Perdagangannya.

Berdasarkan paparan di atas, penulis merasa perlu untuk melakukan evaluasi lebih lanjut mengenai kualitas kelayakan air minum pada Depot Air Minum Isi Ulang (DAMIU) di Kabupaten Sleman, Yogyakarta.

Penelitian ini akan mengkaji dua permasalahan, yaitu :

1. Apakah air minum pada Depot Air Minum Isi Ulang di Kabupaten Sleman mengalami penyimpangan kualitas dari standar yang telah ditentukan sesuai dengan Keputusan Menteri Kesehatan Nomor 907I Menkes/SK/VII/2002 tentang Syarat-Syarat dan Pengawasan Kualitas Air Minum?

2. Faktor-faktor apa saja yang mempengaruhi penyimpangan kualitas air minum pada Depot Air Minum Isi Ulang di Kabupaten Sleman? Tujuan Penelitian adalah :

1. Untukmengetahui apakah air minum pada Depot Air Minum Isi Ulang di Kabupaten Sleman mengalami 
penyimpangan kualitas dari standar yang telah ditentukan sesuai dengan Keputusan Menteri Kesehatan Nomor 907/Menkes/SK/VII/2002 tentang Syarat-Syarat dan Pengawasan Kualitas Air Minum.

2. Untuk mengetahui faktor-faktor apa saja yang mempengaruhi penyimpangan kualitas air minum pada DepotAir Minum Isi Ulang di Kabupaten Sleman.

\section{Penelitian Terdahulu}

Ziqri Rahmadyan, melakukan penelitian tentang Evaluasi Pengendalian Kualitas Produk Air Minum Pada DepotAir Minum Isi Ulang di Kabupaten Sleman, Yogyakarta pada tahun 2007. Dengan menggunakan metode Statistical Quality Control, X-Chart dan P-Chart, ditemukan bahwa terdapat penyimpangan kualitas air minum yang dibuktikan dengan ditemukannya bakteri ecoli pada sejumlah sampel, dengan rata-rata kandungan $0.669874 \mathrm{MPN}$ dengan batas toleransi 0 MPN per $100 \mathrm{ml}$.

Menurut hasil analisis laboratorium Institut Pertanian Bogor pada tahun 2002 (dalam Firdaus Yustisia Sembiring, 2008) bahwa dari 120 sampel air minum isi ulang depot yang diambil dari sepuluh kota besar, diketahui $16 \%$ terkontaminasi bakteri Coli form. Sepuluh kota besar tersebut adalah Jakarta, Tangerang, Bekasi, Bogor, Cikampek, Medan, Denpasar, Yogyakarta, Semarang dan Surabaya.
Hasil penelitian Danandoyo (dalam Zuhri, 2009) menunjukkan bahwa empat dari 12 depot air minum isi ulang di Kota Surakarta terdapat coliform, yaitu depot AR terdapat coliform 7,56 per $100 \mathrm{ml}$, depot AA terdapat coliform 4,26 per $100 \mathrm{ml}$, depot GS terdapat coliform 7,56 per $100 \mathrm{ml}$ ketiganya berada Di Kecamatan Jebres, dan depot $\mathrm{RD}$ terdapat coliform 2,06 per $100 \mathrm{ml}$ yang ada di Kecamatan Pasar Kliwon.

\section{TINJAUAN PUSTAKA}

\section{Pengertian Manajemen Operasional}

Pada dasarnya Manajemen Operasional adalah suatu pengelolaan proses pengubahan atau transformasi atas dimana sumber daya adalah input yang diubah menjadi output berupa barang atau jasa. Menurut Zulian Yamit (1996) manajemen operasi adalah kegiatan untuk mengolah input melalui proses transformasi atau pengubahan atau konversi sedemikian rupa sehingga menjadi output yang dapat berupa barang atau jasa. Krajewski dan Ritzman (dalam Zulian Yamit, 1996) mendefinisikan manajemen operasi sebagai proses transformasi input menjadi output berupa barang atau jasa secara terarah dan sistematis. Sedangkan Jay Heizer dan Barry Render (2006) berpendapat bahwa manajemen operasi adalah serangkaian aktivitas yang menghasilkan nilai dalam bentuk barang dan jasa dengan mengubah input menjadi output. 


\section{Pengertian Kualitas}

Kualitas merupakan suatu istilah relatif yang sangat bergatung pada situasi. Menurut American Society for Quality (dalam Heizer dan Render, 2006) Kualitas adalah keseluruhan fitur dan karakteristik produk atau jasa yang mampu memuaskan kebutuhan yang terlihat atau yang samar.

Philip B. Crosby (dalam Zulian Yamit, 2004) mempersepsikan kualitas sebagai nihil cacat, kesempurnaan dan kesesuaian terhadap persyaratan. Philip B Crosby (dalam Tunggal, 1993), mengusulkan kualitas merupakan suatu bentuk kesesuaian dengan persyaratan (Performance To Requairments). Crosby menjelaskan bahwa angka-angka yang digunakan dalam menilai kesesuaian tersebut merupakan suatu komitmen untuk menghasilkan suatu jumlah tertentu dari material yang tidak sempurna sebelum kita memulai. Tapi, angka-angka tersebut bukanlah standar atau target, angkaangka tersebut adalah sebuah akseptasi (batas penerimaan) yang sederhana mengenai suatu kasus. Akseptasi tersebut juga akan diteruskan dengan perbaikan berkelanjutan.

Juran (dalam Yamit, 2004) mendefinisikan kualitas sebagai kesesuaian terhadap spesifikasi. Menurut Juran, (dalam Yamit, 1996) secara obyektif pengertian kualitas adalah, suatu standar khusus dimana kemampuannya (availability), kinerja (performance), keandalannya (reliability), kemudahan pemeliharaan (maintainability) dan karakteristiknya dapat diukur. Ditinjau dari sudut pandang produsen, kualitas dapat diartikan sebagai kesesuaian dengan spesifikasinya.

Menurut Yamit (1996) suatu produk akan dinyatakan berkualitas oleh produsen, apabila produk tersebut telah sesuai dengan spesifikasinya. Kesesuaian mencakup beberapa unsur, yaitu :

a. Sesuai dengan spesifikasi fisiknya, misalnya ciri khusus, kekerasan, teknologi.

b. Sesuai dengan prosedurnya.

c. Sesuai dengan persyaratannya.

Lebih lanjut Yamit menjelaskan bahwa terdapat tiga ukuran kualitas yang dapat digunakan untuk barang, yaitu :

a. Kualitas desain (design quality)

Kualitas desain barang sangat berhubungan dengan sifat-sifat keunggulan pada saat barang mula-mula diimpikan. Kualitas desain dipengaruhi oleh beberapa faktor, yaitu kualitas input, teknologi yang digunakan, dan kualitas tenaga kerja dan manajer.

b. Kualitas penampilan (performance quality)

Aspek ini mencakup performa produk di masa akan datang, yang dipengaruhi oleh dua faktor, yaitu kendalan produk (reliability of prod$u c t)$ yang berhubungan dengan waktu penggunaan sebelum terjadi kerusakan, dan perawatan produk 
(maintenance of product) yang berhubungan dengan kemampuan mereparasi dan mengganti dengan cepat produk yang rusak.

c. Kualitas yang memenuhi (conformance quality)

Berhubunggan dengan apakah produk yang dihasilkan memenuhi spesifikasi yang tela ditetapkan atau yang diharapkan, dengan kata lain sejauh mana kualitas produk dapat dicapai. Dalam hal ini terdapat tiga faktor yang mempengaruhi conformance quality, yaitu usia teknik produk (technical life of prod$u c t$ ), pengaruh produk (impacts of product), dan ketepatan produk (accuracy of product).

\section{Faktor-faktor Yang Mempengaruhi}

\section{Kualitas}

Menurut Zulian Yamit (1996) secara umum faktor-faktor yang mempengaruhi kualitas dapat diklasifikasikan sebagai berikut :

a. Fasilitas operasi seperti kondisi fisik bangunan,

b. Peralatan dan perlengkapan (tools and equipment)

c. Bahan baku atau material,

d. Pekerjaan ataupun staf organisasi. Secara khusus faktor-faktor yang mempengaruhi kualitas diuraikan sebagai berikut:

a. Pasar dan tingkat persaingan.

Persaingan harga merupakan faktor penentu dalam menetapkan tingkat kualitas output suatu perusahaan untuk menghasilkan produk berkualitas.

b. Tujuan Organisasi (Organization Objectives)

Keinginan perusahaan untuk menghasilkan volume output yang tinggi, barang yang berharga mahal dan eksklusif.

c. Testing Produksi (Product Testing)

Testing dan inspeksi terhadap produk yang dihasilkan untuk mengetahui dan mengungkapkan kekurangan produk tersebut lebih awal.

d. Desain Produk (Product Design)

Bentuk dan desain produk dapat mempengaruhi nilai jual dipasaran dan dari hal tersebut dapat dilihat keberhasilan suatu produk.

e. Proses Produksi (Production Process)

Prosedur dalam proses produksi dapat mempengaruhi kualitas dari suatu produk.

f. Kualitas Input ( Quality Of Inputs)

Pengaruh yang besar dari bahan, tenaga kerja, dan juga peralatan yang tidak tepat, dapat berakibat fatal pada produk.

g. Perawatan Perlengkapan (Equipment Of Maintenance)

Perawatan terhadap mesin produksi yang berkala, dapat mengurangi resiko kegagalan suatu produk dan mesin yang tidak dirawat, akan menurunkan kualitas barang yang diproduksi dengan sendirinya. 
Evaluasi Pengendalian Kualitas Air Minum pada Baziedy

h. Stāndar'Kualitas (Quality Standar)

Perhatian terhadap kualitas dengan melakukan testing atau inspeksi, dapat menghasilkan output yang berkualitas.

i. Umpan Balik Konsumen (Customer Feedback)

Sensitif terhadap keluhankeluhan dari konsumen walaupun pengaruhnya terhadap tumbuhnya kualitas tidak terlalu signifikan.

\section{Kualitas Air Minum}

Dalam Keputusan Menteri Kesehatan Republik Indonesia Nomor 907 Tahun 2002 Tentang Syarat-Syarat dan Pengawasan Kualitas Air Minum, disebutkan bahwa, "Air Minum adalah air yang melalui proses pengolahan atau tanpa proses pengolahan yang memenuhi syarat kesehatan dan dapat langsung diminum". Persyaratan kesehatan air minum dalam Keputusan Menteri Kesehatan tersebut meliputi persyaratan bakteriologis, kimiawi, radio aktif dan fisik.

Menurut $\mathrm{Ni}$ Luh Putu Manik Widiyanti dan Ni Putu Ristiati (2004) kualitas air menyangkut :

1.Kualitas fisik, yang meliputi kekeruhan, temperatur, warna, bau dan rasa. Kekeruhan air dapat ditimbulkan oleh adanya bahanbahan organik dan anorganik yang terkandung di dalam air seperti lumpur dan bahan-bahan yang berasal dari buangan. Dari segi estetika, kekeruhan di dalam air dihubungkan dengan kemungkinan pencemaran oleh air buangan.

2. Kualitas kimia, yang berhubungan dengan ion-ion senyawa ataupun logam yang membahayakan, di samping residu dari senyawa lainnya yang bersifat racun, seperti antara lain residu pestisida. Dengan adanya senyawa-senyawa ini kemungkinan besar bau, rasa dan warna air akan berubah, seperti yang umum disebabkan oleh adanya perubahan $\mathrm{pH}$ air. Pada saat ini kelompok logam berat seperti $\mathrm{Hg}, \mathrm{Ag}, \mathrm{Pb}, \mathrm{Cu}, \mathrm{Zn}$, tidak diharapkan kehadirannya di dalam air.

3. Kualitas biologis, berhubungan dengan kehadiran mikroba patogen (penyebab penyakit, terutama penyakit perut), pencemar (terutama bakteri coli) dan penghasil toksin.

\section{Pengertian Pengawasan Kualitas}

Pengawasan kualitas merupakan salah satu faktor penting dalam keberhasilan perusahaan. Dengan pengawasan kualitas yang baik, perusahaan dapat memberikan jaminan kepada konsumen, dimana hal tersebut dapat meningkatkan kepercayaan dan loyalitas konsumen terhadap produk. Pada umumnya kegiatan pengawasan kualitas perusahaan dilakukan oleh bagian pengawasan kualitas yang menjaga kualitas produk agar sesuai dengan standar kualitas yang telah ditetapkan. 
Menurut Assauri (1993) yang dimaksud dengan pengawasan adalah kegiatan pemeriksaan dan pengendalian atas kegiatan yang telah dan sedang dilakukan, agarkegiatan-kegiatan tersebut dapat sesuai dengan apa yang diharapkan atau yang direncanakan.

Satria (2006) berpendapat bahwa pengawasan merupakan aktivitas agar dapat menemukan, mengoreksi penyimpangan-penyimpangan penting dalam hasil yang dicapai dari aktivitasaktivitas yang telah direncanakan sebelumnya.

Menurut Ishikawa (1989) Melaksanakan pengendalian kualitas adalah mengembangkan, mendesain, memproduksi dan meberikan jasa produk yang bermutu yang paling ekonomis, paling berguna dan selalu memuaskan bagi konsumen.

Dari berbagai definisi tersebut dapat disimpulkan bahwa pengawasan kualitas adalah proses pemeriksaan, pengukuran, dan perbandingan kualitas produk dengan spesifikasi, persyaratan, atau standar yang telah ditetapkan sebelumnya.

\section{Tujuan Pengendalian Kualitas}

Pengendalian kualitas merupakan hal yang penting yang menjadi tanggungjawab penuh bagi perusahaan untuk menjamin kualitas produknya dan juga penunjang bagi keberhasilan perusahaan. Menurut Yamit (1996) ada beberapa tujuan dalam pengendalian kualitas, yaitu :
1. Untuk menekan atau mengurangi volume kesalahan dan perbaikan.

2. Untuk menjaga atau menaikkan kualitas sesuai standar.

3. Untuk mengurangi keluhan atau perolehan konsumen.

4. Memungkinkan pengkelasan output (output grading).

5. Untuk mentaati peraturan.

6. Untuk menaikkan atau menjaga company image.

Satria (2006) menjelaskan bahwa pengawasan kualitas digunakan untuk memperbaiki kegagalan atau penyimpangan yang tidak diinginkan dan juga untuk menjamin tercapainya tujuan serta terlaksananya rencana yang telah digariskan. Penyimpangan yang terjadi itu sendiri merupakan bahan pertimbangan dalam penyusunan rencana pada masa yang akan datang.

Kesimpulan yang dapat diambil dari teori diatas adalah bahwa kualitas mencakup sejauh mana suatu produk memenuhi persyaratan, spesifikasi, atau standar yang telah ditentukan. Pengendalian kualitas dilakukan agar produsen mampu mengendalikan serta mengawasi terwujudnya kualitas barang yang diproduksi dan memenuhi kepuasan konsumen. Pengendalian kualitas air minum di Depot Air Minum Isi Ulang merupakan hal yang sangat penting ditengah maraknya isu tentang buruknya kualitas air minum isi ulang. Selain untuk menjaga kualitas air minum agar sesuai dengan Kepmenkes nomor 907 tahun 2002 tentang persyaratan kualitas air 
minum, juga untuk menjaga kepercayaan dan loyalitas konsumen akan air minum isi ulang yang akan berdampak positif bagi DepotAir Minum Isi Ulang itu sendiri.

\section{METODE PENELITIAN}

\section{Variabel Penelitian}

Dalam penelitian ini, penulis menggunakan beberapa variabel sebagai bahan penelitian yaitu, kandungan bakteri E-coli, kandungan $\mathrm{Fe}$ (besi), kandungan $\mathrm{pH}$, kejemihan atau wama, rasa, dan bau.

\section{Definisi Operasional Variabel}

\section{a. Pengendalian Kualitas Variabel}

Variabel adalah karakteristik produk yang memiliki dimensi dan dapat diukur. Adapaun variabel produk air minum yang akan diteliti adalah :

1). Kandungan bakteri E-coli

Air minum yang sesuai dengan Kepmenkes nomor 907 tahun 2002 adalah air minum yang tidak mengandung bakteri E-coli. Bakteri Escherichia coli, atau biasa disingkat $E$-coli, adalah salah satu jenis spesies utama bakteri gram negatif (wikipedia). Bakteri E-coliè memiliki koloni, yang masing-masing koloni. tidak memiliki jumlah yang tetap, karena bakteri tersebut dapat berkembang biak ataupun mati, sehingga dalam pengukurannya bakteri E-coli menggunakan satuan MPN (Most Probability Number).

2).Kandungan $\mathrm{Fe}$ (besi)

Adalah kandungan mineral yang terdapat dalam air minum. Je- nis logam yang terkandung dalam air ini, merupakan senyawa yang berbentuk batangan logam, dengan batas aman untuk dikonsumsi menurut Kepmenkes nomor 907 tahun 2002 maksimal sebesar $0,3 \mathrm{mg} / \mathrm{L}$. Menurut Athena, D. Anwar M, Hendro dan M. Muhasim (2004) masuknya logam berat ke dalam tubuh dapat melalui kulit, inhalasi (pemafasan) maupun lewat makanan /minuman, keberadaan logam berat dalam tubh manusia pada kadar tertentu dapat menimbulkan dampak pada kesehatan. Mengkonsumsi $\mathrm{Fe}$ (besi) secara berlebihan dapat menyebabkan keracunan, terutama pada anak-anak. Jika kandungan Fe yang dimiliki air minum melebihi standar yang telah ditetapkan maka produk air minum isi ulang tersebut dinyatakan tidak berkualitas.

3).Kandungan $\mathrm{pH}$

$\mathrm{pH}$ adalah derajat keasaman yang digunakan untuk menyatakan tingkat keasaman atau kebasaan yang dimiliki oleh suatu larutan (wikipedia). Batas aman pH untuk dikonsumsi menurut Kepmenkes nomor 907 tahun 2002 adalah 6,5 sampai 8,5.

\section{b. Pengendalian Kualitas Atribut}

Atribut merupakan karakteristik produk yang tidak dapat dihitung atau diwakili oleh angka atau numerik. Atribut produk dalam penelitian ini meliputi: 
1). Kejernihan (warna) air

Daiam kamus besar Indonesia, kata jernih memiliki arti bening, tidak keruh; tidak berwarna apapun, dapat dijelaskan bahwa air terang, bersih, dan tidak memiliki warna buram karena kotor debu atau endapan zat lainnya (Badudu, 2001). Kriteria yang didapat atas kejernihan dari produsen adalah dimana air tersebut tidak memiliki warna (termasuk tidak buram) dan bersih dari endapan kotoran atau endapan unsur logam apapun. Air yang dihasilkan harus memenuhi kriteria seperti yang telah disebutkan diatas. Menurut Wibowo (2010) air yang bersih tidak akan berwarna, sehingga tampak bening atau jernih. Bila kondisi air warnanya berubah maka hal tersebut merupakan salah satu indikasi bahwa air telah tercemar.

2). Rasa

Apabila air meiliki rasa dan aroma, maka air tersebut bisa dikatakan tidak bagus. Dalam Kamus Besar Bahasa Indonesia, rasa diartikan sebagai segala sesuatu yang terkecap oleh lidah manusia, baik itu manis, asam, asin, pahit, panas, dan dingin (Badudu, 2001). Berdasarkan Kepmenkes nomor 907 tahun 2002, airyang layak minum adalah air yang tidak berasa.

3). Bau

Dalam Kamus Besar Bahasa Indonesia bau memiliki arti yaitu segala sesuatu yang tertangkap oleh indera penciuman, meliputi bau yang harum, atau juga bau yang busuk (Badudu, 2001). Menurut Singgih Tri Wibowo (2010) timbulnya bau pada air merupakan indikasi kuat bahwa air telah tercemar. Berdasarkan Kepmenkes nomor 907 tahun 2002, air yang layak minum adalah air yang tidak berbau.

\section{Jenis dan Teknik Pengumpulan Data}

\section{a. Jenis Data}

Data yang diambil oleh penulis bersifat kualitatif dan kuantitatif, dimana data yang ada adalah fakta dan dapat dipertanggungjawabkan. Data dapat dibedakan menjadi dua, yaitu :

1).Data primer, yang diperoleh dari hasil pengamatan sendiri dan bersumber dari objek penelitian, data diperoleh dari metode observasi dan wawancara.

2).Data sekunder, yang diperoleh bukan atas usaha sendiri, tetapi berasal dari sumber lain yang relevan. Dalam penelitian ini, data sekunder yang digunakan adalah hasil uji laboratorium terakreditasi.

\section{b. Teknik Pengumpulan Data}

Data primer dapat diperoleh langsung dari sumber yang diamati. Antara lain melalui:

\section{Metode observasi}

Merupakan suatu metode yang dilakukan dengan cara pengamatan dan pencatatan langsung secara sistematis terhadap gejala-gejala yang diselidiki. Dalam hal ini, data 
yang penulis ambil melalui metode observasi adalah sampel air minum dan tempat operasi DAMIU. Air minum tersebut penulis amati berdasarkan parameter fisik air minum yang dapat diamati namun tidak dapat diukur, yaitu tentang kejernihan (warna), rasa, dan bau. Disamping itu penulis juga mengamati tempat, mesin, dan peralatan di masing-masing DAMIU.

2. Metode interview/ wawancara

Interview atau wawancara merupakan metode pengumpulan dengan cara mengadakan wawancara atau tanya jawab secara langsung untuk mendapatkan data yang diperlukan. Metode ini dilakukan untuk mendukung pendugaan faktorfaktor penyebab penyimpangan kualitas yang terjadi di Depot Air Minum Isi Ulang yang mengacu pada Keputusan Menteri Perindustrian dan Perdagangan Republik Indonesia Nomor 651/MPP/Kep/10/2004 tentang Persyaratan Teknis DepotAir Minum dan Perdagangannya.

Data sekunder yang digunakan oleh penulis adalah data hasil uji laboratorium dari setiap sampel air minum yang telah di ambil di sepuluh Depot Air Minum Isi Ulang di Kabupaten Sleman tentang kandungan bakteri E-coli, $\mathrm{pH}$, dan Fe di laboratorium terakreditasi ISO 17025.

\section{Metode Analisis Data}

\section{a. Pengendalian Kualitas Variabel}

Pengendalian variabel dapat dinya- takan dalam bentuk ukuran angka atau kuantitatif khususnya untuk produk yang cukup banyak. Misalnya dinyatakan dalam dimensi panjang, dimensi berat, dimensi volume, dan dimensi lain yang telah diukur (Yamit, 2004). Dalam penelitian ini penulis menggunakan $X$ chart yang merupakan diagram kontrol rata-rata sebagai alat analisis variabel yang terukur seperti kandungan bakteri E-colie, kandungan $\mathrm{pH}$ dan kandungan Fe (besi).

Menurut Yamit (1996) langkahlangkah dalam menmbuat $X$-chart adalah sebagai berikut :

1. Mengukur atau menghitung ratarata penyimpangan dari kelompok sampel (grand mean).

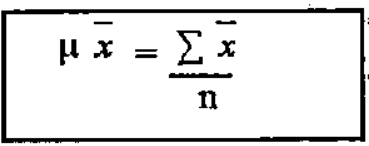

dimana,

$\sum \bar{x}=$ Jumlah dari rata-rata pemeriksaan kelomipok sample,

n = Jumlah sampel dan

$\mu \bar{x}=$ Rala-rata penyimpanan

2. Menghitung besarnya simpangan baku (standard deviasi).

$$
S \overline{\mathrm{x}}=\sqrt{\frac{\sum(\bar{x}-\mu \overrightarrow{\mathrm{x}})^{2}}{n-1}}
$$

dimana,

$S \overline{\mathbf{x}}=$ standar deviasi,

$\mu \bar{x}=$ grand mean

$\bar{x}=$ Rata-rata penyimpangan, dan

n = Jumlah sampel. 
3. Mencari nilai $Z$.

Bila menggunakan nilai konversi

$Z$, maka nilai $Z$ dirumuskan:

$$
Z=\frac{U C L-\mu \bar{x}}{S_{\bar{x}}}
$$

dan atau,

$$
\mathrm{Z}=\frac{\mu_{\overline{\mathrm{x}}}^{-} L C L}{\mathrm{~S}_{\overline{\mathrm{x}}}}
$$

dimana,

$\mathrm{Z}=$ nilai konversi tingkat kerusakan

$\mathrm{UCL}=$ batas kontrol atas.

$\mathrm{LCL}=$ batas kontrol bawah.

$\mu_{\overline{\mathrm{x}}} \quad$ = rata-rata kandungan zat besi.

$\mathrm{S}_{\mathrm{x}}=$ standar deviasi.

\section{b. Pengendalian Kualitas Atribut}

Ada beberapa karakteristik kualitas yang tidak dapat dinyatakan dengan angka numerik, karakteristik tersebut dinamakan atribut atau sifat. Untuk mengklasifikasikan kualitas produk pada umumnya digunakan istilah "sesuai spesifikasi" dan "tidak sesuai spesifikasi", atau "produk baik" dan "produk Yamit (1996) menjelaskan bahwa bagan control yang sering digunakan untuk pengawasan atribut adalah $P$-chart. Langkah-langkah yang dilakukan dalam menyusun bagan kendali ketidak sesuaian $P$-chart adalah sebagai berikut:

1. Mencari mean produk yang rusak

$$
\overline{\mathrm{p}}=\frac{\sum \mathrm{p}}{\mathrm{n}}
$$

2. Mencari standart deviasi

$$
S_{p}=\sqrt{\frac{\bar{p}(1-\bar{p})}{n}}
$$

3. Mencari batas pengawasan Batas pengawasan atau (UCL)

$$
\mathrm{UCL}=\overline{\mathrm{P}}+\mathrm{ZS}_{\mathrm{p}}
$$

Batas pengawasan bawah (LCL)

$$
L C L=\bar{p}-Z_{p}
$$

Keterangan:

$$
\begin{aligned}
\overline{\mathrm{P}} \quad=\text { Mean kerusakan } & \text { Banyak produk cacat } \\
\overline{\mathrm{N}}= & \text { Banyak produk yang } \\
& \text { diobservasi } \\
\mathrm{Z}= & \text { Probabilitas terjadinya } \\
& \text { kerusakan barang } \\
\mathrm{S}_{\mathrm{p}}= & \text { Standar Deviasi } \\
\mathrm{UCL}= & \text { Batas pengawasan atas } \\
\mathrm{LCL}= & \text { Batas pengawasan } \\
& \text { bawah }
\end{aligned}
$$

\section{Diagram Ishikawa}

Menurut Yamit (2004) diagram sebab akibat atau yang juga dikenal dengan diagram ishikawa atau diagram fishbone ini merupakan instrumen dasar dalam peningkatan kualitas. Fungsi dasarnya adalah untuk mengidentifikasikan dan mengorganisasi penyebab-penyebab yang mungkin timbul dari suatu efek spesifik dan kemudian memisahkan akar penyebabnya. Penyebab-penyebab tersebut dapat ditinjau dari beberapa hal seperti dari segi manusia, mesin, sistem yang ada, lingkungan luar, dan lain-lain.

Ishikawa (1989) menjelaskan 
langkah-langkah untuk membuat diagram sebab akibat adalah sebagai berikut :

1. Tentukan karakteristik mutu karena karakteristik inilah yang akan diperbaiki dan dikendalikan.

2. Tulislah karakteristik mutu pada sisi kanan.

3. Tulislah faktor utama yang mungkin menyebabkan gerakan tidak tetap, mengarahkan panah cabang ke panah utama.

4. Kepada setiap item cabang, tulislah kedalamnya faktor rinci yang dapat dianggap sebagai penyebab, yang akan menyerupai ranting.

5. Seorang harus memeriksa untuk memastikan bahwa semua item yang mungkin menjadi penyebab dispersi telah masuk ke dalam diagram.

Bila digambarkan akan tampak sebagai berikut:

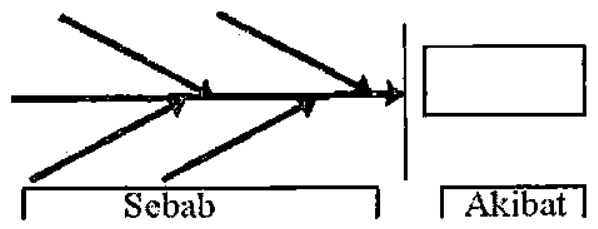

Gambar 1. Diagram Ishikawa

\section{ANALISIS}

Adapun persyaratan dari variabelvariabel penelitian ini telah diatur dalam Peraturan Menteri Kesehatan Nomor 907/Menkes/SK/VII/2002 tentang syarat-syarat dan pengawasan kualitas air minum adalah sebagai berikut :

1. Kandungan bakteri E-colie : $0 \mathrm{MPN}$ (digunakan'sebagai UCL).

2. $\mathrm{pH}$ antara 6,5 (digunakan sebagai
LCL) sampai 8,5 (digunakan sebagai $(\mathrm{CL})$.

3. Kandungan logam $\mathrm{Fe}$ (besi) : 0,3 $\mathrm{mg} / \mathrm{L}$ (digunakan sebagai UCL).

4. Tidak memiliki warna (bening).

5. Tidak memiliki bau.

6. Tidak memiliki rasa.

\section{a. Analisis Kualitas Variabel}

Tabel 1: Hasil uji Kandungan E-Coli

No. Hasil Uji Sampel $\bar{x}(\bar{x}-\mu \bar{x})^{2}$

Depot AMPNiBadincaspin

$\begin{array}{llllll}1 . & 0 & 0 & 0 & 0 & 9,6\end{array}$

$\begin{array}{llllll}2 . & 13 & 13 & 13 & 13 & 10,24\end{array}$

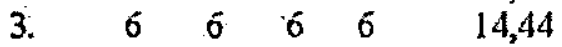

4. $\quad 0.0000009$

5. $\quad 0 \quad 0000000$

6. $\quad 0 \quad 0 \quad 00000$

7. $\quad 29 \quad 29 \quad 29 \quad 29 \quad 368,64$.

$\begin{array}{llllll}\text { 8. } & 0 . & 0 & 0 & 0 & 9,6\end{array}$

9. $46 \quad 46 \quad 46 \quad 46 \quad 1310,44$

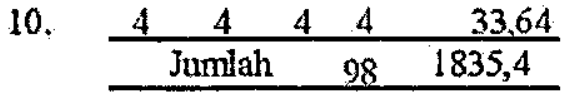

$\mu \bar{x} \quad 9.8$

Sumber: Hasil laboratorium (data diolah) Dari täbel hasil uji e-coli diatas, dibuat perhitungan sebagai berikut:

Dari tabel hasil uji e-coli diatas, dibuat perhitungan sebagai berikut:

1. Rata-rata penyimpangan e-coli : $\begin{aligned} \mu \bar{x} & =\sum \bar{x} \\ \mu \bar{x} & =\frac{98}{10}=9,8\end{aligned}$

2. Standar deviasi :

$$
\begin{aligned}
& S \overline{\mathrm{x}}=\sqrt{\frac{\sum(\bar{x}-\mu \overline{\mathrm{x}})^{2}}{n-1}} \\
& S \overline{\mathrm{x}}=\sqrt{\frac{1835,4}{9}} \\
& S \overline{\mathrm{x}}=14,28
\end{aligned}
$$


3. Mencari nilai $Z$.

$$
\begin{aligned}
& Z=\frac{U C L-\mu_{\vec{z}}}{S_{\tilde{z}}} \\
& Z=\frac{0-9,8}{14,28} \\
& Z=-0,69
\end{aligned}
$$

Jadi probabilitas untuk nilai $Z=-0,69$ adalah 0,2549

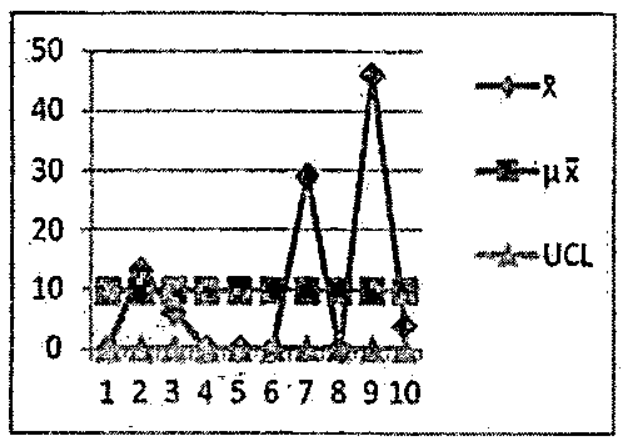

Gambar 2. Grafik Hasil Perhitungan UCL, $\bar{X}$, dan $\mu_{\bar{X}}$ kandungan E-coli.

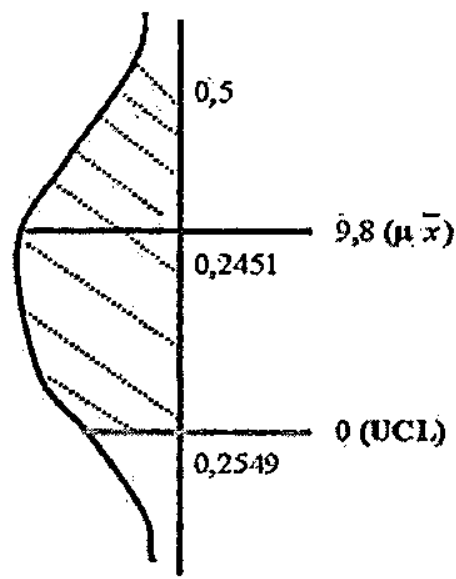

Gambar 3. Grafik Probabilitas

Penyimpangan Kandungan E-coli.

Data hasil uji laboratorium tentang kandungan bakteri e-coli kemudian dilakukan perhitungan. Dari hasil perhitungan di atas, dapat diketahui bahwa, terdapat penyimpangan terhadap kandungan bakteri e-coli pada air minum yang dijadikan sampel penelitian dengan probabilitas penyipangan sebesar 0,7451 atau $74,51 \%$. Temuan ini telah melebihi batas kontrol atas yang sesuai peraturan, yaitu sebesar O MPN.

Tabel 2: Hasil uji Kandungan $\mathrm{pH}$

No. Hasil Uji Sampel $\bar{x}(\bar{x}-\mu \bar{x})^{2}$ Depot

1. $5,84 \quad 5,84 \quad 5,84 \quad 5 ; 84 \quad 1,132$

2. $\quad \begin{array}{llllll}7,24 & 7,24 & 7,24 & 7,24 & 0,112\end{array}$

3. $\quad 5,83 \quad 5,83 \quad 5,83 \quad 5,83 \quad 1,153$

4. $\quad 6,73 \quad 6,73.6,73 \quad 6,73 \quad 0,03$

5. $\quad 6,98 \quad 6,98 \quad 6,98 \quad 6,98 \quad 0,005$

6. $7,16 \quad 7,16 \quad 7,16 \quad 7,16 \quad 0,065$

$\begin{array}{llllll}\text { 7. } & 7,2 & 7,2 & 7,2 & 7,2 & 0,087\end{array}$

8. $\quad 7,66 \quad 7,66 \quad 7,66 \quad 7,66 \quad 0,571$

9. $\quad 7,32 \quad 7,32 \quad 7,32 \quad 7,32 \quad 0,173$

10. $7,08 \quad 7,08 \quad 7,08 \quad 7,08 \quad 0,03$

Jumlah $69,04 \quad 3,358$

$\mu x \quad 6,904$

Sumber : Hasil laboratorium (Data diolah) Dari tabel hasil pengujian $\mathrm{pH}$ diatas dapat dibuat perhitungan sebagai berikut:

1. Rata-rata kandungan $\mathrm{pH}$

$$
\begin{aligned}
& \mu \bar{x}=\sum \bar{x} \\
& \mu \bar{x}=69,04=6,904 \\
& 10
\end{aligned}
$$

2. Standar Deviasi

$$
\begin{aligned}
& S \overline{\mathrm{x}}=\sqrt{\frac{\sum(\bar{x}-\mu \overline{\mathrm{x}})^{2}}{n-1}} \\
& S \overline{\mathrm{x}}=\sqrt{\frac{3,358}{9}}
\end{aligned}
$$


3. Mencari nilai $\mathrm{Z}$.

$$
\begin{aligned}
& Z=\frac{8,5-6,904}{0,61} \\
& Z=2,62
\end{aligned}
$$

Jadi probabilitas untuk nilai $\mathrm{Z}$ untuk $\mathrm{UCL}=2,62$ adalah 0,4956

$$
\begin{array}{ll}
\mathrm{Z} & =\frac{6,904-6,5}{0,61} \\
\mathrm{Z} & =0,66
\end{array}
$$

Jadi probabilitas untuk nilai $\mathrm{Z}$ untuk $\mathrm{LCL}=0,66$ adalah 0,2454

Penyimpangan Kandungan $\mathrm{pH}$

Dari perhitungan di atas dapat diketahui bahwa penyimpangan kandungan $\mathrm{pH}$ pada air minum yang melebihi batas kontrol atas yang sebesar 8,5 memiliki probabilitas sebesar 0,0044 atau 0,44 $\%$, sedangkan yang melewati batas kontrol bawah yang sebesar 6,5 memiliki probabilitas sebesar 0,2456 . atau $24,56 \%$.

Tabel 3 : Hasil uji Kandungan Fe (besi) No. Hasil Uji Sampel $\bar{x}(\bar{x}-\mu \bar{x})^{2}$

Depot A(mg/L) B (mg/L)C(mgL)

$\begin{array}{llllll}\text { 1. } & 0,55 & 0,55 & 0,55 & 0,55 & 0,245 \\ 2 . & 0 & 0 & 0 & 0 & 0,003 \\ 3 . & 0 & 0 & 0 & 0 & 0,003 \\ 4 . & 0 & 0 & 0 & 0 & 0,003 \\ 5 . & 0 & 0 & 0 & 0 & 0,003 \\ 6 . & 0 & 0 & 0 & 0 & 0,003 \\ 7 . & 0 & 0 & 0 & 0 & 0,003 \\ 8 . & 0 & 0 & 0 & 0 & 0,003 \\ 9 . & 0 & 0 & 0 & 0 & 0,003 \\ 10 . & 0 & 0 & 0 & 0 & 0,003\end{array}$
10. 00000003

\begin{tabular}{ccc} 
Jumlah & $0,55 \quad 0,272$ \\
\hline$\mu x$ & 0,055 \\
Suniber : Hasil laboratorium (Data diolah)
\end{tabular}
Dari tabel hasil pengujian $\mathrm{Fe}$ (Besi) diatas, dapat dibuat perhiturigan sebagai berikut :

1. Rata-rata kandungan $\mathrm{Fe}$

$$
\mu \vec{x}=\frac{0,55}{10}=0,055
$$

2. Standar Deviasi

$$
\begin{aligned}
& S \bar{x}=\sqrt{\frac{0,272}{9}} \\
& S \bar{x}=0,17
\end{aligned}
$$

3. Mencari nilai $Z$

$$
Z=0.3-0,055=1,44
$$

$$
0,17
$$

Jadi, nilai probabilitas untuk nilai $Z=$ 1.44 adalah 0.4251

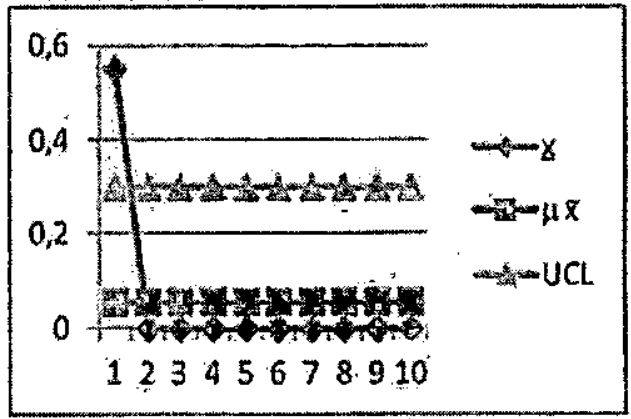

Gambar 6. Grafik Perhitungan UCL,

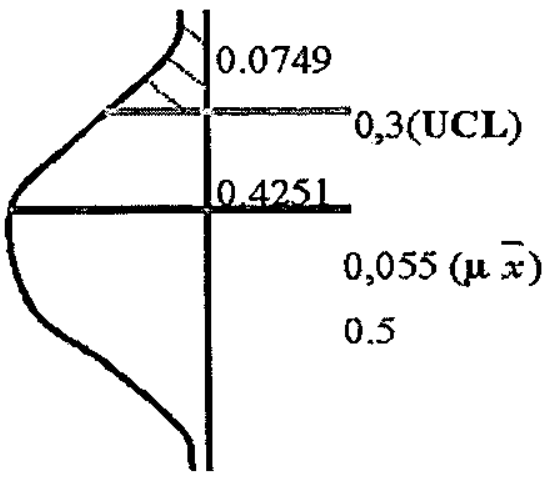

Gambar 7. Grafik Probabilitas Penyimpangan Kandungan $\mathrm{Fe}$ (besi)

Dari perhitungan di atas dapat diketahui bahwa penyimpangan kandungan $\mathrm{Fe}$ pada air minum yang melebihi batas 
kontrol atas yang sebesar 0.3 memiliki probabilitas sebesar 0.0749 atau $7.49 \%$.

Tabel 4: Hasil uii Kejernihan Air

\begin{tabular}{ccc}
\hline No. & \multicolumn{2}{c}{ Hasil Uji Sampel } \\
\cline { 2 - 3 } Depot & Jernih & Keruh \\
\cline { 2 - 3 } 1. & $\mathrm{v}$ & - \\
2. & $\mathrm{v}$ & - \\
3. & $\mathrm{v}$ & - \\
4. & $\mathrm{v}$ & - \\
5. & $\mathrm{v}$ & - \\
6. & $\mathrm{v}$ & - \\
7. & $\mathrm{v}$ & - \\
8. & $\mathrm{v}$ & - \\
9. & $\mathrm{v}$ & - \\
I0. & $\mathrm{v}$ & - \\
Jumlah & $100 \%$ & $0 \%$ \\
\hline
\end{tabular}

\section{b.Analisis Kualitas Atribut}

Dari hasil pengujian di atas, dapat diketahui bahwa, tidak terjadi penyimpangan pada air minum untuk kategori kejernihan, dengan hasil $100 \%$ jernih pada semua sampel yang diperiksa, sehingga dapat disimpulkan bahwa hasil pengujian air minum pada kategori kejernihán bagus dan sesuai dengan standar peraturan yang telah ditentukan.

\section{Tabel 5: Hasil uji Bau Air}

\begin{tabular}{ccc}
\hline No: & \multicolumn{2}{c}{ Hasil Uji Sampel } \\
\cline { 2 - 3 } Depot & Tidak berbau & Berbau \\
\cline { 2 - 3 } 1. & $\mathrm{v}$ & - \\
2. & $\mathrm{v}$ & - \\
3. & $\mathrm{v}$ & - \\
4. & $\mathrm{~V}$ & - \\
5. & $\mathrm{v}$ & - \\
6. & $\mathrm{v}$ & - \\
7. & $\mathrm{v}$ & - \\
8. & $\mathrm{v}$ & - \\
9. & $\mathrm{v}$ & - \\
10. & $\mathrm{v}$ & - \\
\hline
\end{tabular}

\begin{tabular}{lll}
\hline Jumlah $100 \%$ & $0 \%$ \\
\hline
\end{tabular}

bahwa tidak terjadi penyimpangan sama sekali pada air minum untuk kategori bau, dengan hasil $100 \%$ tidak berbau pada semua sampel yang diperiksa, sehingga dapat disimpulkan bahwa hasil pengujian air minum pada kategori ini bagus. Tabel 6: Hasil uji Rasa Air

\begin{tabular}{|c|c|c|}
\hline \multirow{2}{*}{$\begin{array}{l}\text { No. } \\
\text { Depot }\end{array}$} & \multicolumn{2}{|c|}{ Hasil Uji Sampel } \\
\hline & Tidak berasa & Berasa \\
\hline 1. & $\mathbf{v}$ & - \\
\hline 2. & $\mathrm{v}$ & - \\
\hline 3. & $\mathrm{v}$ & - \\
\hline 4. & $\mathrm{v}$ & - \\
\hline 5. & $\mathbf{v}$ & - \\
\hline 6. & $\mathrm{v}$ & - \\
\hline 7. & $\mathrm{v}$ & - \\
\hline 8. & $\mathrm{v}$ & - \\
\hline 9. & $\mathbf{v}$ & - \\
\hline 10. & $\mathrm{v}$ & - \\
\hline & lah $100 \%$ & $0 \%$ \\
\hline
\end{tabular}

Dari hasil pengujian di atas, diketahui bahwa tidak terjadi penyimpangan sama sekali pada air minum untuk kategori rasa, dengan hasil $100 \%$ tidak berasa pada semua sampel yang diperiksa, sehingga dapat disimpulkan bahwa hasil pengujian air minum pada kategori ini bagus.

\section{c. Diagram Ishikawa (Diagram Sebab-Akibat)}

Sebelum membuat diagram sebabakibat, penulis melakukan analisis kualitatif untuk menguatkan dugaan faktor-faktor penyebab penyimpangan kualitas air minum. Analisis kualitatif tersebut berasal dari hasil wawancara kepada pengusaha depot dan pengamatan peralatan, mesin, dan proses pengisian air minum di masing-masing 
depot. Observasi dan wawancara tersebut mengacu pada Keputusan Menteri Perindustrian dan Perdagangan Republik Indonesia Nomor 651/MPP/Kep/10/ 2004 tentang Persyaratan Teknis Depot Air Minum dan Perdagangannya.

Tabel 7: Hasil wawancara

\begin{tabular}{lcc}
\hline No. & Lama & Uji Air \\
Depot & Beroperasi (Th) & \multicolumn{1}{c}{ Baku } \\
\cline { 2 - 3 } 1. & 4 & $\mathrm{x}$ \\
2. & 3 & $\mathrm{x}$ \\
3. & 4 & $\mathrm{x}$ \\
4. & 2 & $\mathrm{x}$ \\
5. & 6 & $\mathrm{x}$ \\
6. & 5 & $\mathrm{x}$ \\
7. & 4 & $\mathrm{x}$ \\
8. & 1 & $\mathrm{x}$ \\
9. & 2 & $\mathrm{x}$ \\
10. & 2 & $\mathrm{x}$ \\
\hline
\end{tabular}

Sumber: Hasil wawancara

Dari tabel hasil wawancara tersebut dapat diketahui bahwa semua depot telah beroperasi selama lebih dari 6 bulan. Rata-rata masa operasi depot tersebut adalah 3,3 tahun. Hal tersebut menunjukkan bahwa seharusnya semua depot dalam penelitian ini telah melakukan uji air baku ulang, dimana dalam Keputusan Menteri Perindustrian dan Perdagangan Republik Indonesia Nomor 651/MPP/Kep/10/2004 tentang Persyaratan Teknis Depot Air Minum dan Perdagangannya, DepotAir Minum Isi Ulang harus melakukan uji ulang air baku tiga bulan sekali untuk kandungan bakteri, dan minimal dua kali dalam setahun untuk analisa kimia dan fisika secara lengkap.

Hasil wawancara tersebut juga menunjukkan bahwa semua Depot Air
Minum Isi Ulang yang dijadikan sampel penelitian, selama beroperasi tidak pernah melakukan uji ulang air baku yang selama ini digunakan.

Tabel 8: Hasil observasi dan wawancara No. Semua alat Service mesin dan Depot berbahan peralatan food grade

\begin{tabular}{lll}
1. & $\mathrm{v}$ & $\mathrm{x}$ \\
2. & $\mathrm{x}$ & $\mathrm{x}$ \\
3. & $\mathrm{x}$ & $\mathrm{x}$ \\
4. & $\mathrm{v}$ & $\mathrm{x}$ \\
5. & $\mathrm{~V}$ & $\mathrm{~V}$ \\
6. & $\mathrm{v}$ & $\mathrm{V}$ \\
7. & $\mathrm{x}$ & $\mathrm{x}$ \\
8. & $\mathrm{v}$ & $\mathrm{x}$ \\
9. & $\mathrm{x}$ & $\mathrm{x}$ \\
10. & $\mathrm{x}$ & $\mathrm{x}$ \\
\hline
\end{tabular}

$\overline{\text { Sumber: Hasil observasi dan wawancara }}$

Hasil observasi dan wawancara di atas menunjukkan bahwa pada beberapa depot, tidak semua peralatan yang digunakan terbuat dari bahan yang standar, yaitu bahan food grade. Tidak semua depot pernah melakukan service mesin dan peralatan.

Tabel 9: Hasil wawancara

\begin{tabular}{lcc}
$\begin{array}{l}\text { No. } \\
\text { Depot }\end{array}$ & $\begin{array}{c}\text { Penggantian } \\
\text { filter yang jenuh }\end{array}$ & $\begin{array}{c}\text { Sanitasi } \\
\text { permukaan } \\
\text { peralatan } \\
\text { setiaphari }\end{array}$ \\
\hline 1. & $\mathrm{X}$ & $\mathrm{x}$ \\
2. & $\mathrm{x}$ & $\mathrm{x}$ \\
3. & $\mathrm{X}$ & $\mathrm{x}$ \\
4. & $\mathrm{x}$ & $\mathrm{x}$ \\
5. & $\mathrm{v}$ & $\mathrm{x}$ \\
6. & $\mathrm{~V}$ & $\mathrm{x}$ \\
7. & $\mathrm{x}$ & $\mathrm{x}$ \\
8. & $\mathrm{x}$ & $\mathrm{x}$ \\
9. & $\mathrm{x}$ & $\mathrm{x}$ \\
10. & $\mathrm{x}$ & $\mathrm{x}$ \\
\hline
\end{tabular}

Sumber: Hasil wawancara 
Hasil wawancara di atas menunjukkan bahwa pada beberapa depot, serta mengganti filter. Semua depot yang dijadikan sampel penelitian tidak melakukan pembersihan dan sanitasi permukaan peralatan yang kontak dengan bahan baku dan air minum setiap hari.

Tabel 10: Hasil observasi

\begin{tabular}{lcc}
$\begin{array}{l}\text { No. } \\
\text { Depot karyawan sesuai }\end{array}$ & $\begin{array}{c}\text { Karyawan } \\
\text { mencuci } \\
\text { tangan sebelum } \\
\text { penanganan }\end{array}$ \\
\cline { 3 - 3 } 1. & $\mathrm{x}$ & $\mathrm{x}$ \\
2. & $\mathrm{x}$ & $\mathrm{x}$ \\
3. & $\mathrm{x}$ & $\mathrm{x}$ \\
4. & $\mathrm{x}$ & $\mathrm{x}$ \\
5. & $\mathrm{x}$ & $\mathrm{x}$ \\
6. & $\mathrm{x}$ & $\mathrm{x}$ \\
7. & $\mathrm{x}$ & $\mathrm{x}$ \\
8. & $\mathrm{x}$ & $\mathrm{x}$ \\
9. & $\mathrm{x}$ & $\mathrm{x}$ \\
10. & $\mathrm{x}$ & $\mathrm{x}$ \\
\hline
\end{tabular}

Sumber: Hasil observasi

Hasil observasi di atas menunjukkan bahwa, pada semua depot yang dijadikan sampel penelitian, para karyawan tidak menggunakan pakaian yang sesuai standar, yaitu pakaian kerja, tutup kepala, dan sepatu. Pada semua depot yang dijadikan sampel penelitian, para karyawan tidak mencuci tangan sebelum penanganan pengisian air.

\section{KESIMPULAN DAN SARAN}

\section{a. Kesimpulan}

Kesimpulan yang dapat diambil dari penelitian ini adalah sebagai berikut :

1).Berdasarkan hasil pemeriksaan laboratorium terakreditasi ISO 17025 dan hasil analisis pengawasan kualitas menggunakan $X$-chart, diketahui bahwa terdapat penyimpangan kualitas air minum pada kategori pengawasan kualitas variabel.

Sebanyak 50\% DepotAir Minum Isi Ulang di Kabupaten Sleman yang dijadikan sampel penelitian tercemar oleh bakteri $\mathrm{E}$-coli, dengan ratarata $9.8 \mathrm{MPN}$ per $100 \mathrm{ml}$. Hal tersebut melebihi batas kontrol atas kandungan bakteri E-coli yang sesuai dengan Peraturan Menteri Kese-

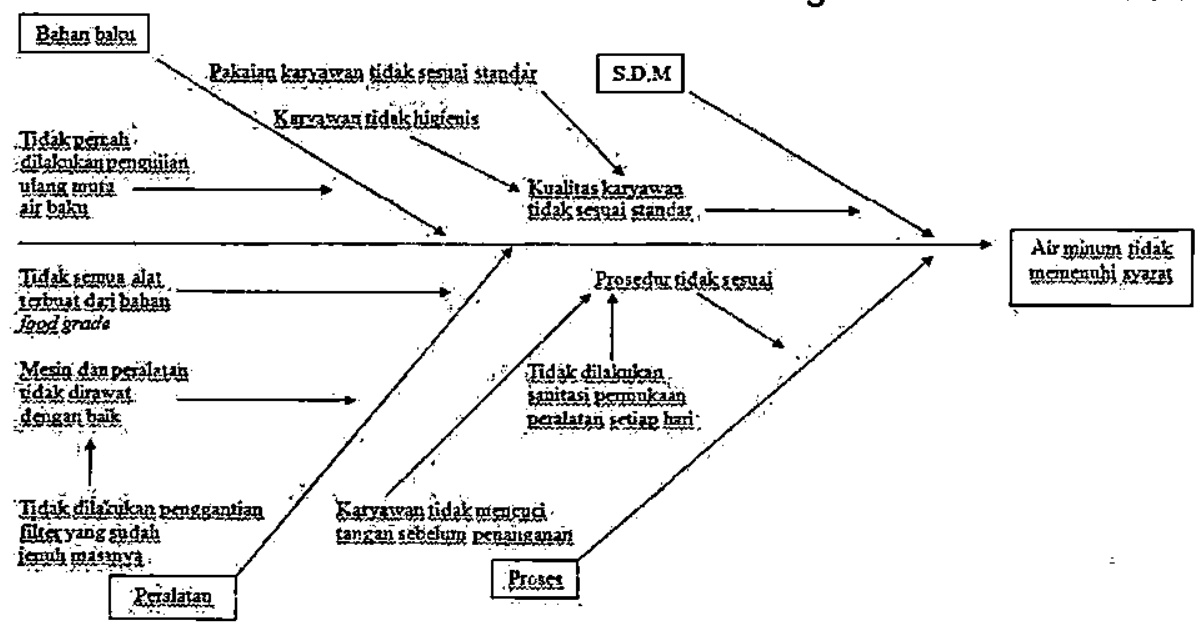

Gambar 8. Diagram Ishikawa (Faktor-faktor Penyebab Penyimpangan kualitas air minum 
hatan Nomor 907/Menkes/SKIVIII 2002 tentang Syarat dan Pengawasan Kualitas Air Minum yaitu sebesar 0 MPN per $100 \mathrm{ml}$.

Sebanyak 20\% Depot Air Minum Isi Ulang di Kabupaten Sleman yang dijadikan sampel penelitian memiliki $\mathrm{pH}$ dibawah batas kontrol bawah yang sesuai dengan Peraturan Menteri Kesehatan Nomor 907/ Menkes/SKNII/2002 tentang Syarat dan Pengawasan Kualitas Air Minum yaitu 6,5. Tidak ada Depot Air Minum Isi Ulang di Kabupaten Sleman yang melebihi batas kontrol atas yang sebesar 8,5. Rata-rata kandungan $\mathrm{pH}$ air minum di Depot Air Minum Isi Ulang di Kabupaten Sleman yang dijadikan sampel penelitian adalah 6,904 .

Sebanyak 10\% Depot Air Minum Isi Ulang di Kabupaten Sleman yang dijadikan sampel penelitian memiliki kandungan $\mathrm{Fe}$ (besi) melebihi batas kontrol atas yang sesuai dengan Peraturan Menteri Kesehatan Nomor 907/Menkes/SK/VII/2002 tentang Syarat dan Pengawasan Kualitas Air Minum yaitu 0,3 mg/L. Rata-rata kandungan $\mathrm{Fe}$ (besi) air minum di DepotAir Minum Isi Ulang di Kabupaten Sleman yang dijadikan sampel penelitian adalah 0,055 $\mathrm{mg} / \mathrm{L}$.

Berdasarkan hasil observasi dan analisis pengawasan kualitas menggunakan $P$-chart, diketahui bahwa tidak terdapat penyimpangan kua- litas air minum pada kategori pengawasan kualitas atribut, berupa kejerinhan (warna), rasa, dan bau. 2).Terjadinya penyimpangan kualitas air minum di Depot Air Minum Isi Ulang di Kabupaten Sieman yang dijadikan sampel penelitian disebabkan oleh beberapa faktor. Faktor-faktor tersebut yaitu :

- Bahan baku air minum yaitu berupa air baku yang digunakan belum tentu baik dan memenuhi persyaratan air baku. Air baku yang diperoleh dari pemasok tidak pernah diuji ulang Air minum tidak memenuhi syarat oleh para pengusaha Depot Air Minum Isi Ulang di laboratorium yang terkareditasi tentang semua parameter air minum, baik parameter fisik, kimia, maupun biologi.

- Mesin dan peralatan tidak dirawat dengan baik. Tidak semua peralatan yang digunakan terbuat dari bahan food grade (tara pangan) yang aman digunakan untuk makanari dan minuman. Kebanyakan alat yang tidak terbuat dari bahan food grade adalah pipa, baik pipa yang berasal dari alat penampungan air baku, pipa yang terhubung ke filter, desinfektan, sampai pipa tempat keluaran air minum ke wadah pelanggan. Beberapa depot juga belum pernah mengganti filter, dimana jika dilihat dari lama depot beroperasi, seharusnya filter sudah harus diganti. 
- Kualitas karyawanAir minum tidak memenuhi syarat tidak sesuai standar. Hal tersebut dapat dilihat dari pakaian karyawan yang tidak sesuai standar, sehingga tangan karyawan menjadi tidak bersih atau higienis. Belum lagi jika karyawan merokok, makan, atau meludah, dimana hal tersebut dapat mencemari air minum.

- Prosedur yang dilakukan saat penanganan atau pelayanan kepada konsumen tidak sesuai. Di semua depot yang dijadikan sampel penelitian, semua karyawan tidak mencuci tangan sebelum melakukan penanganan.

\section{b. Saran}

1. Depot Air Minum harus melakukan pengawasan secara periodik terhadap mutu air baku, yang ditunjukkan dengan hasil uji laboratorium, seperti yang tercantum pada pasal 3 ayat 2, Keputusan Menteri Perindustrian dan Perdagangan Nomor 651/MPP/Kep/l0/ 2004. Dalam ayat 3 dijelaskan bahwa pengujian mutu air baku dilakukan minimal satu kali dalam tiga bulan untuk analisa coliform, dan dua kali dalam satu tahun untuk analisa kimia dan fisika secara lengkap.

2. Seluruh mesin dan peralatan yang kontak langsung dengan air, termasuk pipa harus terbuat dari bahan tara pangan (food grade), tahan korosi dan tidak bereaksi dengan bahan kimia, seperti yang dimaksud oleh pasal 5, Keputusan Menteri Perindustrian dan Perdagangan Nomor 651/MPP /Kep/l0/ 2004. Sehingga saat proses produksi dilakukan air tersebut aman dan tidak terkontaminasi.

3. Seperti yang dimaksud dalam pasal 5, Keputusan Menteri Perindustrian dan Perdagangan Nomor 651/MPP /Kep/l0/2004, bahwa karyawan yang berhubungan dengan produksi harus dalam keadaan sehat, bebas dari luka, penyakit kulit atau hal lain yang diduga dapat mengakibatkan pencemaran terhadap air minum. Karyawan bagian produksi (pengisian) diharuskan menggunakan pakaian kerjà, tutup kepala dan sepatu yang sesuai. Karyawan harus mencuci tangan sebelum melakukan pekerjaan, terutama pada saat penanganan wadah dan pengisian. Karyawan tidak diperbolehkan makan, merokok, meludah atau melakukan tindakan lain selama melakukan pekerjaan yang dapat menyebabkan pencemaran terhadap air minum.

4. Dinas Kesehatan Kabupaten/Kota selaku pihak yang berwenang untuk melaksanakan pengawasan kualitas air minum sesuai dengan pasal 4 ayat 1, Keputusan Menteri Kesehatan Nomor 907/MENKES/ SK/VII/2002, dapat bekerja sama dengan dinas terkait dalam melakukan pengawasan kualitas air 
minum pada Depot Air Minum Isi Ulang di Kabupaten Sleman. Sebaiknya frekuensi pengawasan kualitas ditambah, tidak hanya dilaksanakan pada saat depot akan melakukan perpanjangan izin saja, tetapi juga di waktu yang lain secara tiba-tiba atau inspeksi. Hal tersebut dirasa perlu demi terjaminnya kualitas air minum dan tercapainya kualitas kesehatan masyarakat.

\section{DAFTAR PUSTAKA}

Assauri, S. (1993). Manajemen Produksi dan Operasi. Edisi Empat Jakarta: LPFE UI.

Athena, D. Anwar M, Hendro. M., Muhasim. (2004). Kandunagn $\mathrm{Pb}$, $\mathrm{Cd}, \mathrm{Hg}$, Dalam Air Minum dari Depot Air Minum Isi Ulang di Jakarta, Tangerang, dan Bekasi. Jumal Ekologi Kesehatan Vol3 No 3, Desember 2004 : 148 - 152, diperoleh pada 28 November $2010 \mathrm{di}$ : http:/l www.ekologi.litbang. depkes.go.id/ data/vol\%203/Athena3_3.pdf -

Badudu, (2001). Kamus Besar Bahasa Idonesia, Edisi ketiga. Jakarta : Balai Pustaka.

Heizer, J dan Barry R. (2006). Manajemen Operasi. Edisi Tujuh. Jakarta : Penerbit Salemba Empat.

Ishikawa, K. (1989). Teknik Penuntun Pengendalian Mutu. Jakarta : PT Melton Putra.

Rahmadyan, Z. (2007). Evaluasi Pengendalian Kualitas Prodük Air Minum Pada Depot Air Munum Isi
Ulang diKabupaten Sleman, Yogyakarta. Skripsi Sarjana (Tidak dipublikasikan). Yogyakarta: Fakultas Ekonomi Universitas Islam Indonesia. Republik Indonesia. 2004. Keputusan Menteri Perindustrian dan Perdagangan Nomor 651/MPP/Kep/l0/ 2004 tentang Persyaratan Teknis Depot Air Minum dan Perdagangannya, diperoleh pada 28 November $2010 \mathrm{di}$ : http://dinkes-sulsel. go.id/new/images/pdf/Peraturan/ kmk\%20 syarat $\% 20$ dan $\% 20$ pengawasan\% 2 0kualitas \%20air\% 20minum\% 20907-2002.pdf.

Republik Indonesia. 2002. Keputusan Menteri Kesehatan Nomor 907I MENKES/SKIVII/2002 tentang Syarat-Syarat dan Pengawasan Kualitas Air Minum, diperoleh pada 28 November 2010 di : http://uww. kemenperin.go.jd/regulasi/2008/06/ 41.pdf.

Satria, AE. (2006). Analisis Pengawasan Kualitas Priduk Pada CV. Citakarya Furniture (Funimart) Yogyakarta. Skripsi Sarjana (Tidak dipublikasikan). Yogyakarta: Fakultas Ekonomi Universitas Islam Indonesia.

Sembiring, FY. (2008). Manajemen Pengawasan Sanitasi Lingkungan Dan Kualitas Bakteriologis Pada Depot Air Minum Isi Ulang kota Batam. Tesis Magister Kesehatan. Medan : Sekolah Pasca Sarjana Universitas Sumatera Utara, diperoleh pada 28 November 2010 di: http://repository.usu.ac.id/ 
bitstream/123456789/4723/6/

Chapter\%20l.pdf.

Tunggal, AW. (1993). Manajemen Mutu

Terpadu Suatu Pengantar. Jakarta:

PT. Rineka Cipta.

Sembiring, FY. (2008). Manajemen

Pengawasan Sanitasi Lingkungan

Dan Kualitas Bakteriologis Pada

Depot Air Minum Isi Ulang kota Batam. Tesis Magister Kesehatan.

Medan : Sekolah Pasca Sarjana Universitas Sumatera Utara, diperoleh pada 28 November 2010 di : http://repository. usu.ac.id/ bitstream/123456789/4723/6/ Chapter.\%201.pdf.

Wibowo, ST. (2010). Evaluasi Pengolahan Air Minum Pada Instalasi Pengolahan Air (IPA) Jurug Perusahaan Daerah Air Minum (PDAM) Kota Surakarta. Tesis Magister IImu Lingkungan. Surakarta : Program Studi llmu Lingkungan Program Pasca Sarjana Universitas Sebelas Maret, diperoleh pada 28 November $2010 \mathrm{di}$ : http:// digilib.uns.ac.id/upload/dokumen/ 171841512201011011.pdf

Widiyanti, Ni Luh Putu Manik dan Ni Putu Ristiati. (2004). Analisis Kualitatif Bakteri Koliform Pada
Depo Air Minum Isi Ulang di Kota Singaraja Bali. Jurnal Ekologi Kesehatan Vol 3 No 1, April 2004 : $64-73$, diperoleh pada 28 November $2010 \mathrm{di}:$ http://www.ekologi .litbang.depkes.go.id/data/.../ Ni\%20Putu\%20_2.pdf.

Wikipedia. (2010). Escherichia coli, diperoleh pada 28 November 2010 di : http://id.wikipedia.org/wiki/ Escherichia_coli

Wikipedia. (2010). $p H$, diperoleh pada 28 November $2010 \mathrm{di}:$ http:// id.wikipedia.org/wiki/PH.

Yamit, Z. (1996). Manajemen Produksi Dan Operasi. Edisi Pertama. Yogyakarta : Ekonisia.

Yamit, Z. (2004). Manajemen Kualitas Produk dan Jasa. Edisi Pertama. Yogyakarta : Penerbit Ekonisia Kampus Fakultas Ekonomi UII.

Zuhri, S. (2009). Pemeriksaan Mikrobiologis Air Minum Isi Ulang di Kecamatan Jebres Kota Surakarta. Skripsi Sarjana. Surakarta : Fakultas Farmasi Universitas Muhammadiyah Surakarta, diperoleh pada 28 November 2010 di : http://etd.eprints. ums.ac.id/ 5997/1/K100010048.pdf 